\title{
Variability for nuclear ribosomal genes within Theobroma cacao
}

\author{
VALERIE LAURENT, ANGE-MARIE RISTERUCCI \& CLAIRE LANAUD \\ BIOTROP, CIRAD-CP, BP5035, 34032 Montpellier cedex, France
}

\begin{abstract}
Restriction fragment length of the rRNA genes was studied in Theobroma cacao using heterologous rDNA probes. One hundred and ninety-two individuals including both cultivated and wild clones were analysed. DraI and EcoRI restriction sites were mapped. Both length heterogeneity and restriction site polymorphism have been found. Fifteen different types of rDNA units have been characterized. As opposed to previous enzymatic studies, the rRNA gene analysis indicates a clear distinction of the three genetic groups Criollo, Forastero and Trinitario within cocoa and points out the hybrid origin of Trinitario.
\end{abstract}

Keywords: genetic diversity, RFLP, ribosomal RNA genes, Theobroma cacao.

\section{Introduction}

Cocoa trees, Theobroma cacao, which are native to humid tropical regions of the American continent, are classified into three different groups depending on geographic location and morphological characteristics (Cheesman, 1944). The three groups are designated Criollo, Forastero and Trinitario. The Criollo group is composed of trees with thick, white or rosy beans which yield the most flavoured and finest chocolate. They were the first cocoa trees to be domesticated. Criollo have been cultivated in Central America for 2000 years but they are, at present, grown infrequently because of their weakness and their susceptibility to disease. The Forastero group represent more than 80 per cent of the world's production. The Forastero are split into Lower Amazon Forastero and Upper Amazon Forastero but very different populations remain pooled in these two subgroups. The Lower Amazon Forastero were cultivated in the Amazon basin and were the first cocoa trees to be introduced into Africa. The Upper Amazon Forastero, which were collected more recently, are highly diversified and are often used in breeding programmes due to their strength, precocity and resistance to disease. The third group, Trinitario, is made up of hybrid forms of the first two groups. However, the morphological distinction between Criollo and Trinitario is not obvious and many uncertainties exist about the classification of individuals in Criollo or Trinitario groups.

Correspondence: C. Lanaud.
The high morphological variability found among the different populations in the Upper Amazon has resulted in this region being considered to be the centre of origin of the species (Cheesman, 1944). Similarly, isozyme analyses designated this area as the primary centre of diversity (Lanaud, 1987).

Until now, most crop improvement programmes were based on crosses between Trinitario and Upper Amazon Forastero or between Lower Amazon Forastero and Upper Amazon Forastero to obtain fine tasting chocolate from vigorous and productive trees. Since all breeding strategies are based on crosses between clones of various groups, it is of special importance to understand the structure of the genetic variability of the species for refining the current classification. The first genetic markers used for studying a large number of cocoa genotypes were isozymes (Lanaud, 1987). Molecular markers and particularly RAPD have been recently applied on a smaller number of cocoa genotypes (Wilde et al., 1992; Figueira et al., 1992).

In this paper, we analyse the polymorphism of the ribosomal RNA genes (rDNA) within 192 clones of $T$. cacao. In plants, nuclear genes encoding ribosomal RNA are present in high copy number and are arranged in arrays of tandem repeats located at a few loci in the genome usually associated with the nucleolar organizers. Each unit is composed of an intergenic spacer (IGS) and a region coding for the $18 \mathrm{~S}, 5.8 \mathrm{~S}$ and $25 \mathrm{~S}$ rRNAs (Rogers \& Bendich, 1987). Coding regions are highly conserved between different species and genera (Appels \& Dvorak, 1982) while the IGS shows intra and interspecific variation. 


\section{Materials and methods}

\section{Plant material}

A sample of 192 cocoa clones from various areas belonging to the three different groups (Table 1) was surveyed. Both cultivated and wild clones were represented. Dried leaves of the different clones were obtained from IDEFOR-DCC (Ivory Coast), IRCC (France), CRU (Trinidad), CENIAP (Venezuela), CEPLAC (Brazil) and CATIE (Costa Rica).

The classification proposed in Table 1 takes into account that some clones originated from open pollination and, therefore, that some discrepancy might have occurred between the parental type and the progeny. All hybrid forms involving Forastero and Criollo are considered as Trinitario whatever the number of generations since the initial cross.

\section{DNA probes}

Several rDNA probes were used for hybridization. The pTA71 probe corresponds to the entire rRNA gene of wheat (Gerlach \& Bedbrook, 1979). Two probes derived from pTA71 were also used. They correspond to a $3.7 \mathrm{~kb} \mathrm{BamHI}$ fragment located within the coding sequence (pTA71b) and to a $4.4 \mathrm{~kb} E c o \mathrm{RI}-B a m \mathrm{HI}$ fragment overlapping the intergenic spacer and the edges of the coding region (pTA71e-b) (provided by Quetier, Laboratoire de Biologie Moléculaire Végétale, Université Paris XI). The pRG3 probe covers almost the entire coding region of the $18 \mathrm{~S}$ rDNA from radish (Grellet et al., 1989).

\section{RFLP procedures}

Half a gram of dried leaves were ground and incubated $1 \mathrm{~h}$ at $55^{\circ} \mathrm{C}$ and then $10 \mathrm{~min}$ at $65^{\circ} \mathrm{C}$ in $16 \mathrm{ml}$ of extraction buffer $(0.16 \mathrm{~N}$ sodium citrate, NaEDTA $62 \mathrm{~mm}$, SDS 1.2 per cent, mercaptoethanol $6.2 \mathrm{~mm}$, proteinase$\mathrm{K} 1.25 \mathrm{mg}$ and PVP $1 \mathrm{~g}$ ). After incubation at $0^{\circ} \mathrm{C}$ for 10 min with $5 \mathrm{ml}$ of $5 \mathrm{M}$ potassium acetate, $9 \mathrm{ml}$ of phenolchloroform: isoamylalcohol (25:24:1) were added and the subsequent emulsion was centrifuged at $4200 \mathrm{~g}$ for $1 \mathrm{~h}$. The aqueous phase was mixed to $9 \mathrm{ml}$ of isopropanol and the DNA precipitate was immediately spooled out and resuspended in TE buffer $(50 \mathrm{~mm}$ Tris- $\mathrm{HCl} \mathrm{pH} 8,10 \mathrm{~mm}$ NaEDTA). The solution was then incubated with $80 \mu \mathrm{g}$ of RNAse T1 for $30 \mathrm{~min}$ at $37^{\circ} \mathrm{C}$ and DNA was precipitated at $4^{\circ} \mathrm{C}$ for $10 \mathrm{~min}$ with 0.1 volume of $100 \mathrm{~mm}$ sodium acetate and 2.5 volumes of ethanol. After $20 \mathrm{~min}$ microfuge centrifugation, the DNA pellet was washed with 80 per cent ethanol and resuspended in TE buffer. DNA was then purified by an ultracentrifugation in caesium chloride-ethidium bromide gradient.

Five micrograms of DNA were digested overnight by $3 \mathrm{UE} / \mu \mathrm{g}$ of the restriction endonucleases, $D \mathrm{raI}$ and EcoRI. DNA from 12 clones was submitted to a double digestion using the same restriction endonucleases. Restriction fragments were separated in 0.7 per cent agarose gel with Tris acetate NaEDTA buffer for $16 \mathrm{~h}$ at $1.04 \mathrm{~V} \mathrm{~cm}^{-1}$. Fragments were Southern blotted onto nylon Hybond $\mathrm{N}+$ membranes in $0.4 \mathrm{~N}$ $\mathrm{NaOH}$. Probes were labelled with ${ }^{32} \mathrm{P}$ by random priming. Pre-hybridization and hybridizations were performed at $68^{\circ} \mathrm{C}$ overnight in $6 \times \mathrm{SSC}, 5 \times$ Denhardt, 0.5 per cent SDS, $25 \mu \mathrm{g} \mathrm{ml}^{-1}$ herring sperm DNA. Blots were washed at $68^{\circ} \mathrm{C} 30 \mathrm{~min}$ in $2 \times \mathrm{SSC}$ twice, 30 $\min$ in $2 \times \mathrm{SSC}, 0.1$ per cent $\mathrm{SDS}$ and $30 \mathrm{~min}$ in $0.1 \times \mathrm{SSC}, 0.1$ per cent SDS.

\section{Results}

\section{EcoRl and Dral restriction map of rDNA unit}

rDNA hybridization patterns obtained after digestion with EcoRI and DraI, either individually or as double digestion, were compared for preliminary restriction mapping. All clones were characterized by a $3.6 \mathrm{~kb}$ EcoRI fragment (Fig. 1a) corresponding to the coding region (Fig. 2). One to three additional fragments varying from 4.7 to $6.4 \mathrm{~kb}$ in length hybridize to the pTA71 probe.

Digestion with DraI gives similar results. All individuals were characterized by a $5 \mathrm{~kb}$ DraI fragment and one to three variable bands ranging from 3.2 to $5 \mathrm{~kb}$ (Fig. 1b). The DraI site in the coding region must be located in the middle of the EcoRI fragment since hybridization with the pTA71 probe on a double digested DNA led to two fragments of $1.8 \mathrm{~kb}$ instead of one of $3.6 \mathrm{~kb}$ (Fig. 3). The $5 \mathrm{~kb}$ DraI fragment and the $3.2 \mathrm{~kb}$ fragment generated by double digestion hybridize both with probes corresponding to conserved, pTA71b, and variable regions, pTA71e-b (Fig. 3), and thus must overlap the coding region and the intergenic spacer. Furthermore, these fragments also hybridize with the $18 \mathrm{~S}$ probe, pRG3, (Fig. 3) indicating that the involved coding sequence includes the $18 \mathrm{~S}$ coding region (Fig. 2).

On the basis of this scheme, the variable bands of each clone were used to identify the different rDNA units. Variations are revealed between as well as within individuals. Indeed, some individuals bear more than one variable band (e.g. Por3, SIAL42 and SF23 on Fig. 1) which define more than one rDNA unit type. All individuals considered, 15 different rDNA repeat units were defined (Fig. 2). Regarding rDNA units 8, 9, 10, 
Table 1 Constitution of the different rDNA groups. For each group, clones are grouped according to their presumed classification $(\mathrm{C}=$ Criollo, $\mathrm{T}=$ Trinitario, $\mathrm{L}=$ Lower Amazonian Forastero and $\mathrm{U}=$ Upper Amazonian Forastero $)$ and their country of origin or selection. Clones deriving from open pollination are indicated by $\mathrm{dl}$

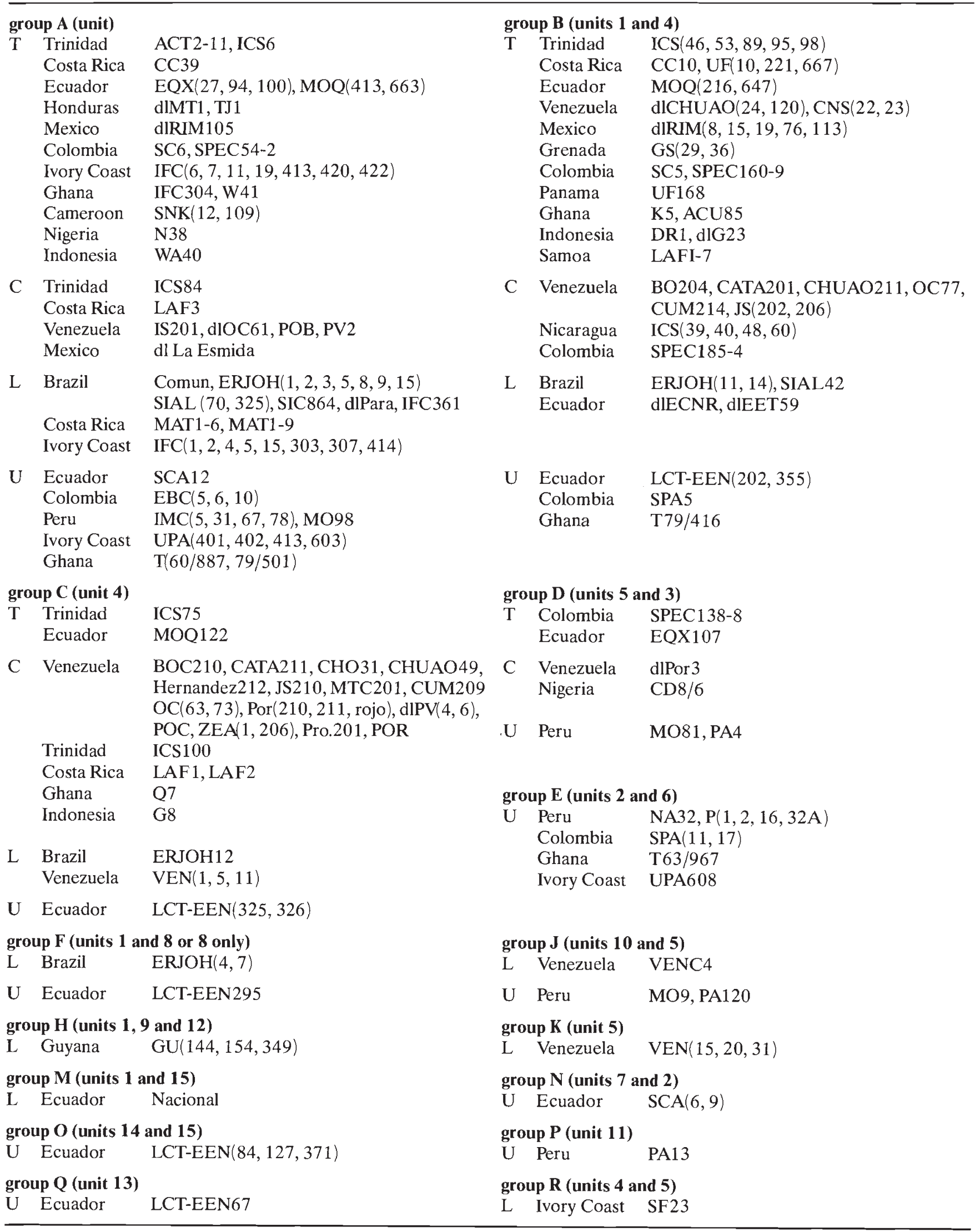




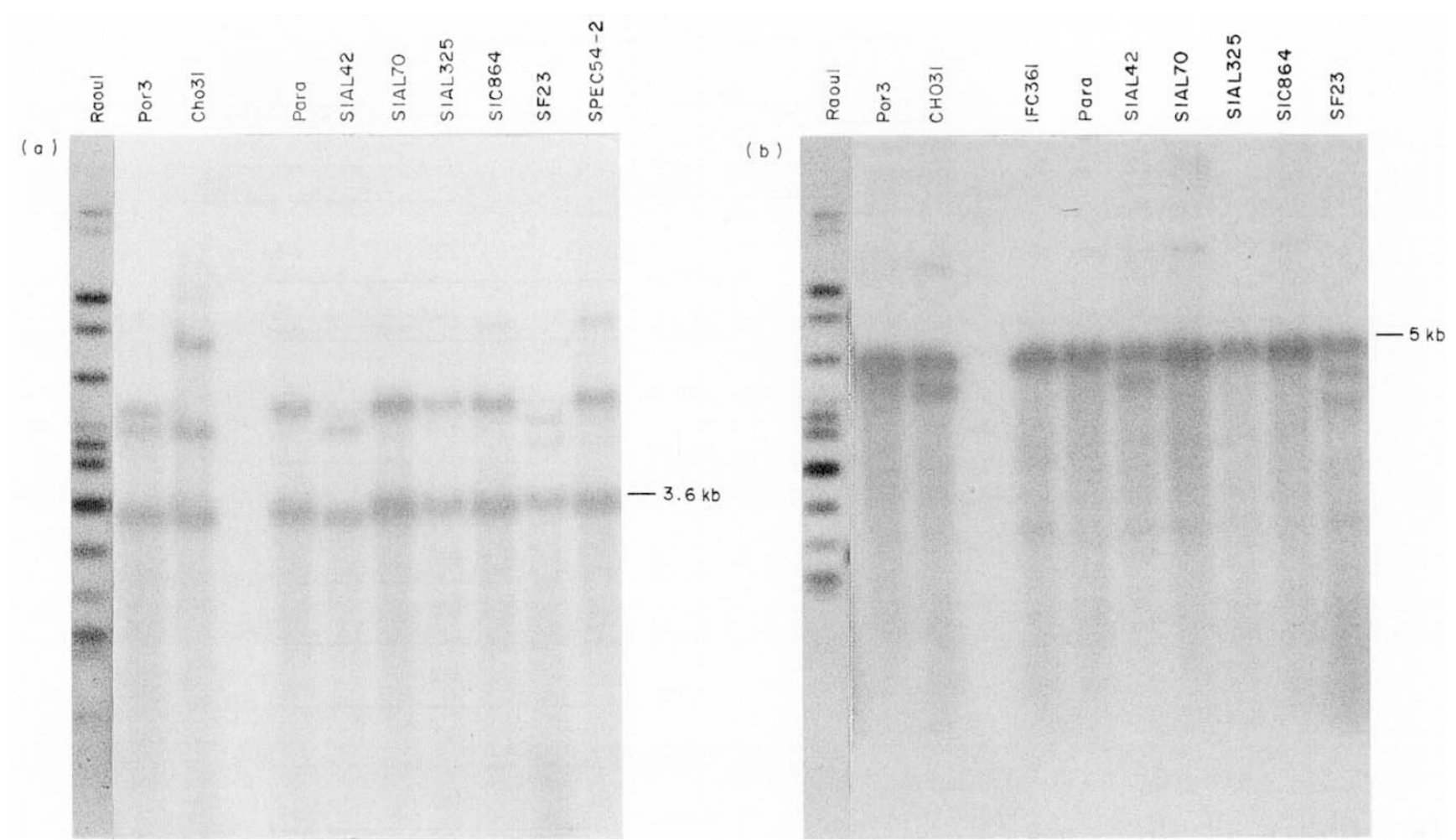

Fig. 1 Example of rDNA polymorphism between different cocoa genotypes revealed by the pTA71 probe on EcoRI (a) and DraI (b) digests. The size of the conserved fragments is indicated on the right. The faint bands larger than $5 \mathrm{~kb}$ were not taken into account in the interpretation since they are suspected to derive from partial digestion. Raoul sizes are 18.5, 14.9, 9, 7.4, 5.6, $4.4,3.9,3.5,2.9,2.3,1.8$ and $1.4 \mathrm{~kb}$.

11,12 and 13 , the difference between the total length of the Dral fragments and that of the EcoRI fragments could be due to the presence of an additional DraI site (D) in the intergenic spacer. The non-hybridization of the small DraI fragment of the intergenic spacer with the wheat and radish probes is probably a consequence of the incomplete homology of this region between species. For rDNA units 14 and 15, the total length of the EcoRI fragments is lower than the total length of the DraI fragments. This could indicate the presence of an additional EcoRI site in the $18 \mathrm{~S}$ coding region at 200 bp upstream from the E1 site in rDNA unit 14, whereas in rDNA unit 15, an additional EcoRI site could be located in the $25 \mathrm{~S}$ coding region $300 \mathrm{bp}$ downstream from the E2 site (Fig. 2). This hypothesis is based on the assumption that the fragments of 200 bp and $300 \mathrm{bp}$ are not seen on hybridization because of their small size.

\section{Variability of the rDNA within cocoa species}

Among the 192 clones tested, the clones sharing identical rDNA units were grouped. Fifteen different groups were identified (Table 1 ) which are most of the time defined by one or two rDNA units. Only one out of the 15 groups is characterized by three rDNA unit types which correspond to the presence of three variable bands in the individuals of group $\mathrm{H}$.

Eighty per cent of the clones studied fall into three major groups ( $\mathrm{A}, \mathrm{B}$ and $\mathrm{C})$, the other 12 groups consist of one to nine clones each. Group A is mainly composed of Forastero and African Trinitario. Group B contains mostly American Trinitario along with few Criollo whereas group $\mathrm{C}$ is made up mainly by Criollo. These three groups are based on only two different rDNA units. Group $\mathrm{A}$ and $\mathrm{C}$ are characterized by rDNA unit 1 and 4 respectively, whereas group $B$ is defined by both rDNA units 1 and 4 .

The other 12 groups contain mainly Forastero clones. They are defined by the 15 different rDNA units. Eight very uncommon rDNA units (8 to 15 ), bearing additional restriction sites, allow seven groups ( $\mathrm{F}, \mathrm{H}, \mathrm{J}, \mathrm{M}, \mathrm{O}, \mathrm{P}$ and $\mathrm{Q}$ ) to be clearly identified. These groups are essentially composed of Upper Amazon clones, with only few clones from Lower Amazon (VEN, GUI). 
Fig. 2 Diversity of the rDNA repeat
units within Theobroma cacao species
The general organization of rRNA
genes is described with the position of
the EcoRI (E1, E2) and DraI (D1, D2
conserved restriction sites and the
length in kb of the conserved frag-
ments. For each unit, the length of the
fragment E1E2 (kb) is reported with
the position of an additional site.

Fig. 2 Diversity of the rDNA repeat
units within Theobroma cacao species.
The general organization of rRNA
genes is described with the position of
the EcoRI (E1, E2) and DraI (D1, D2)
conserved restriction sites and the
length in kb of the conserved frag-
ments. For each unit, the length of the
fragment E1E2 (kb) is reported with
the position of an additional site.

Fig. 2 Diversity of the rDNA repeat
units within Theobroma cacao species
The general organization of rRNA
genes is described with the position of
the EcoRI (E1, E2) and DraI (D1, D2
conserved restriction sites and the
length in kb of the conserved frag-
ments. For each unit, the length of the
fragment E1E2 (kb) is reported with
the position of an additional site.

Fig. 2 Diversity of the rDNA repeat
units within Theobroma cacao species.
The general organization of rRNA
genes is described with the position of
the EcoRI (E1, E2) and DraI (D1, D2)
conserved restriction sites and the
length in kb of the conserved frag-
ments. For each unit, the length of the
fragment E1E2 (kb) is reported with
the position of an additional site.

Fig. 2 Diversity of the rDNA repeat
units within Theobroma cacao species.
The general organization of rRNA
genes is described with the position of
the EcoRI (E1, E2) and DraI (D1, D2)
conserved restriction sites and the
length in kb of the conserved frag-
ments. For each unit, the length of the
fragment E1E2 (kb) is reported with
the position of an additional site.

Fig. 2 Diversity of the rDNA repeat
units within Theobroma cacao species
The general organization of rRNA
genes is described with the position of
the EcoRI (E1, E2) and DraI (D1, D2
conserved restriction sites and the
length in kb of the conserved frag-
ments. For each unit, the length of the
fragment E1E2 (kb) is reported with
the position of an additional site.

Fig. 2 Diversity of the rDNA repeat
units within Theobroma cacao species
The general organization of rRNA
genes is described with the position of
the EcoRI (E1, E2) and DraI (D1, D2
conserved restriction sites and the
length in kb of the conserved frag-
ments. For each unit, the length of the
fragment E1E2 (kb) is reported with
the position of an additional site.

Fig. 2 Diversity of the rDNA repeat
units within Theobroma cacao species
The general organization of rRNA
genes is described with the position of
the EcoRI (E1, E2) and DraI (D1, D2
conserved restriction sites and the
length in kb of the conserved frag-
ments. For each unit, the length of the
fragment E1E2 (kb) is reported with
the position of an additional site.

Fig. 2 Diversity of the rDNA repeat
units within Theobroma cacao species
The general organization of rRNA
genes is described with the position of
the EcoRI (E1, E2) and DraI (D1, D2
conserved restriction sites and the
length in kb of the conserved frag-
ments. For each unit, the length of the
fragment E1E2 (kb) is reported with
the position of an additional site.

Fig. 2 Diversity of the rDNA repeat
units within Theobroma cacao species
The general organization of rRNA
genes is described with the position of
the EcoRI (E1, E2) and DraI (D1, D2
conserved restriction sites and the
length in kb of the conserved frag-
ments. For each unit, the length of the
fragment E1E2 (kb) is reported with
the position of an additional site.
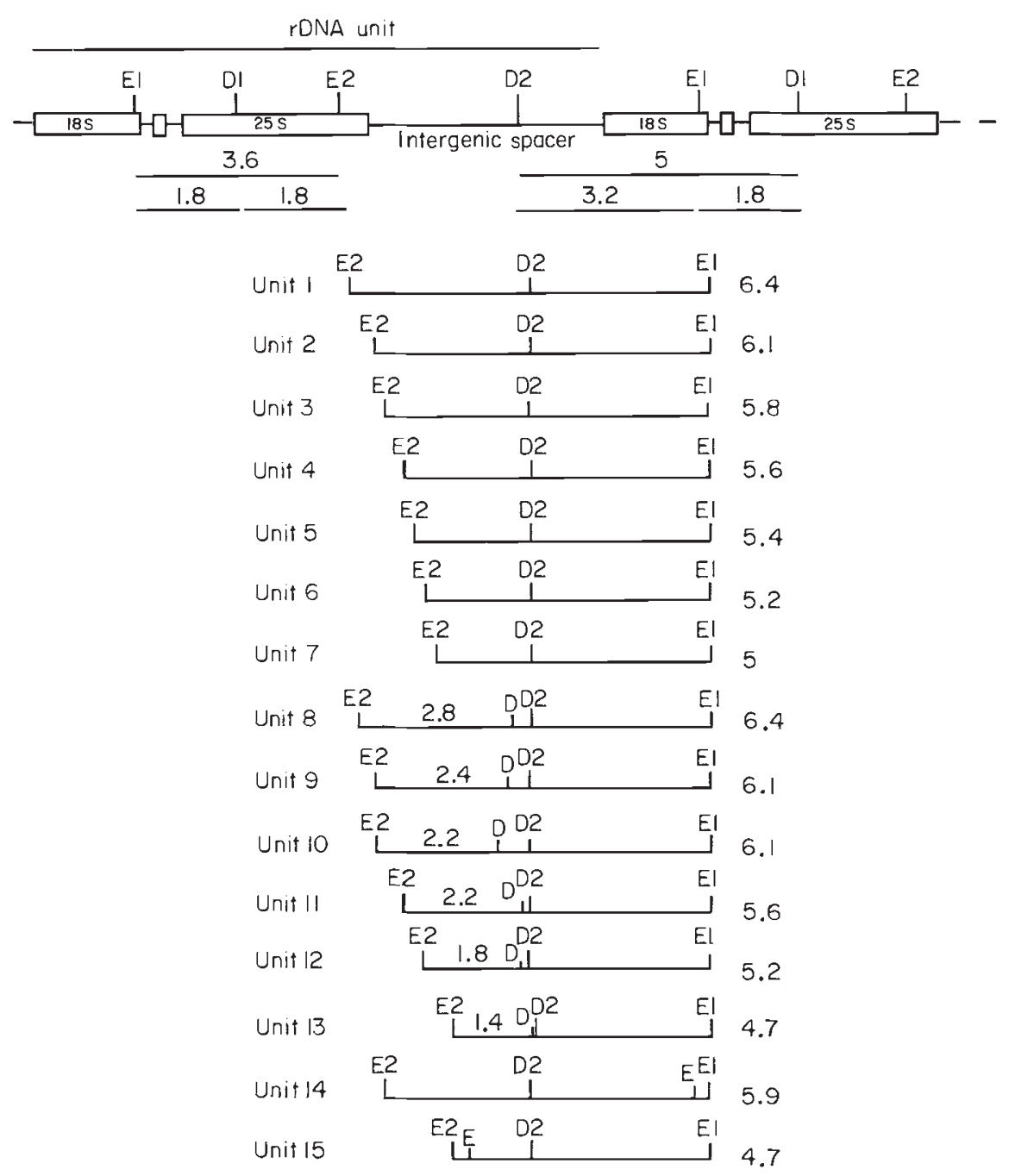

radish (Delcasso-Tremoussaygue et al., 1988), several crucifers (Delseny et al., 1990) and rubber tree (Besse, personal communication). Although DraI has been reported to cut only once in the intergenic spacer of some plants (Delseny, personal communication; Levesque et al., 1990), the combined presence of a conserved DraI fragment of $4.9 \mathrm{~kb}$ with additional variable bands shown in onion (Harvey, 1991) is similar to the $5 \mathrm{~kb}$ conserved fragment and one to three variable bands of cocoa.

Most of the clones show only one or two types of rDNA units indicating that the rRNA genes are most likely located at only one locus. The presence of only one rDNA unit per individual would reflect homozygosity at the rDNA locus whereas the presence of two rDNA units would reflect heterozygosity. This hypothesis is supported by the observation of only one nucleolus per cocoa cell that could reflect the existence of a unique nucleolar organizer in cocoa (Glicenstein \& Fritz, 1989). The presence of three different rDNA reported for several plant species, including pea (Jorgensen et al., 1987), carrot (Taira et al., 1988),

\section{the size and the organization of the coding region are} very commonly found (Delseny, personal communication). Indeed, the two conserved EcoRI sites (E1 and E2) of the cocoa rDNA coding region have been

\section{Discussion}

The results presented in this paper yield original information on the general organization of nuclear rRNA genes of cocoa and on the variability assessment that The general organization of cocoa rRNA genes, based on a number of observations, is very consistent cocoa rDNA unit ranges from 8.3 to $10 \mathrm{~kb}$ which is within the size range of a number of other plant rDNA coding region $(6 \mathrm{~kb})$ and organization of the $18 \mathrm{~S}, 5.8 \mathrm{~S}$ and $25 \mathrm{~S}$ genes were inferred from other species since the size and the organization of the coding region are with that of other species. The length of the entire 

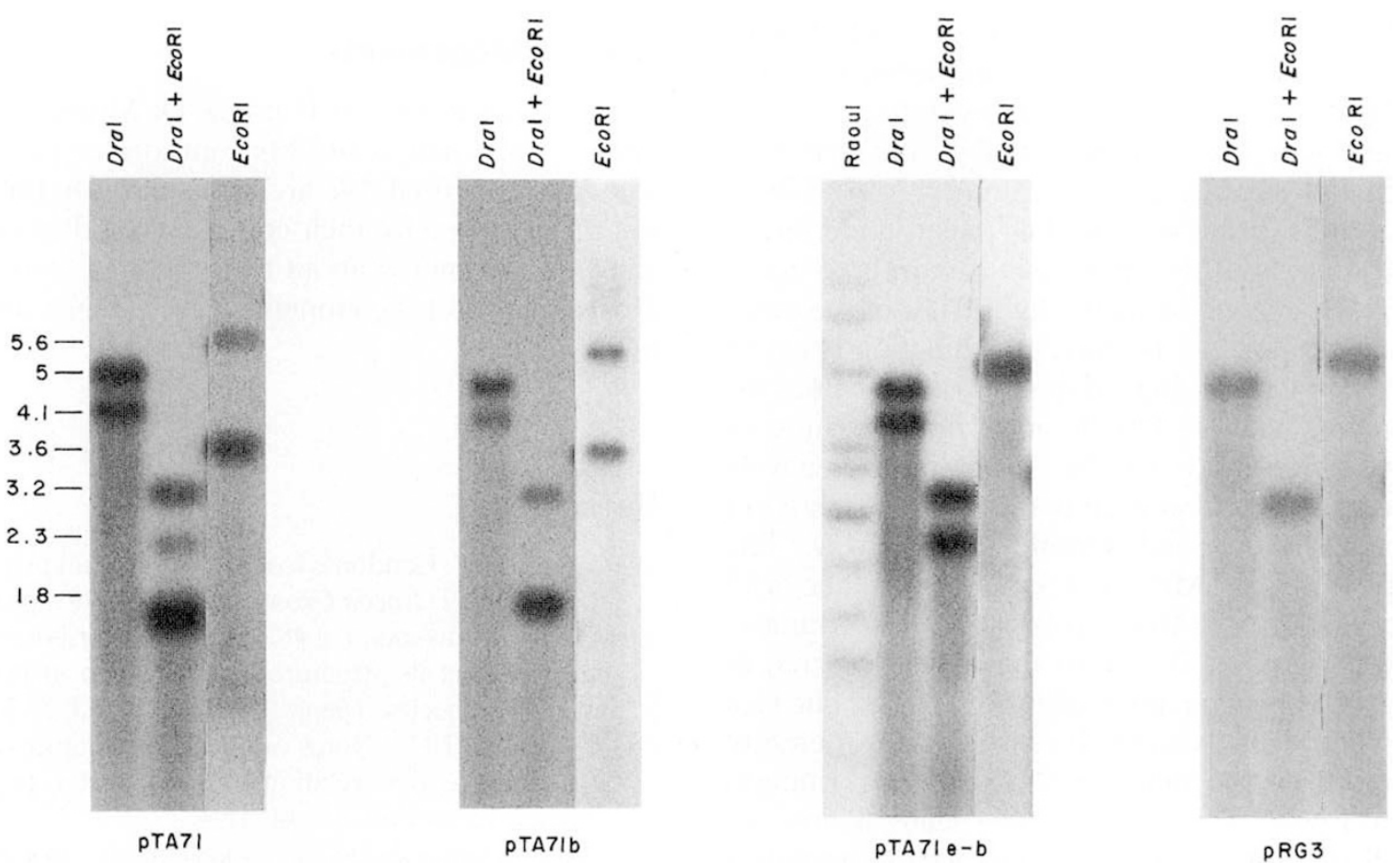

Fig. 3 Hybridization patterns obtained for a clone (CHO31) of group $\mathrm{C}$ with the four different heterologous probes. The sizes of the hybridized fragments $(\mathrm{kb})$ are indicated on the left. Raoul sizes are 9, 7.4, 5.6, 3.9, 3.5, 2.9, 2.3, 1.8 and $1.4 \mathrm{~kb}$.

units in clones of group $\mathrm{H}$ could therefore be explained by the fact that one of the rDNA gene clusters is in a homogenization process. Indeed two of the three bands give a weak hybridization signal and define two rDNA units (9 and 12) that share an additional DraI site. The rDNA 9 and 12 would thus derive from the same chromosome, whereas the rDNA unit 1 would be located on its homologue.

Variability was found both in the length of the intergenic spacer and in the presence of restriction enzyme sites in the coding region and in the intergenic spacer. Variable restriction sites and spacer length variability are commonly found in the intergenic spacer (Zimmer et al., 1988; Glaszmann et al., 1990) while polymorphism of restriction site in the coding region is more unusual although it has been reported for several crucifers (Delseny et al., 1990). Such an extended polymorphism for both restriction site and spacer length has however been reported for cucumber (Kavanagh \& Timmis, 1986) and pea (Jorgensen et al., 1987).

The rDNA gene analysis indicates similarities with the organization of the cocoa species based on morphological characters, isozyme markers and geographical origins.

rRNA genes, as well as morphological characters (Pound, 1938; Allen, 1987), and isozymic markers (Lanaud, 1987), indicate the presence of the greatest variability among clones originated from the Upper Amazon region, supporting the hypothesis that this region is the primary centre of diversity. Lower Amazon Forastero clones constitute a rather homogeneous group with rDNA units bearing no additional restriction site. However, some wild Guyanese clones (GU) have rDNA units with an additional DraI site, as seen in some Upper Amazon clones. Similarly, their isozymic patterns are closer to the LCT-EEN Upper Amazon ones than to the isozymic patterns of other Lower Amazons (Lanaud, 1987). These clones could arise from a diversification scheme different from the one that gave rise to the majority of the Lower Amazon clones.

In some other cases, rDNA genotypes grouped together clones with the same morphological characteristics. Such a correlation is illustrated by the clustering of some Forastero clones (LCT-EEN325, 326 and VEN1, 5 and 11) which have Criollo-like large, white, rosy or light purple beans (Allen, 1987; Lanaud et al., 1986), with the Criollo group (group C). Another example is found in the classification of some clones derived from the Nacional variety (Lower Amazon Forastero). The clones ECNR and EET59 (group B) are classified as Nacional genotypes although they are suspected to derive from a hybridization with a Venezuelan Trinitario type (Bartley, personal communication). The rRNA gene analysis also suggests their close relationship to American Trinitario. 
rDNA restriction patterns are often highly homogeneous within a population and, considering the relatively rapid rate of concerted evolution of the ribosomal gene sequences, exhibit characteristic heterogeneity between groups (Zimmer et al., 1988). Indeed, results presented in this paper underline a strong structuring of the rRNA genes into three major groups $(\mathrm{A}, \mathrm{B}, \mathrm{C})$, one being the hybrid $(\mathrm{B})$ of the other two $(A, C)$ supporting the current distinction between Forastero and Criollo. Indeed in spite of difficulties for discriminating between Criollo and Trinitario, most of the clones reported to be Trinitario effectively appeared as hybrids between two homogeneous types made of Forastero and Criollo, respectively. The grouping of some African Trinitario together with Forastero could result from crosses between Trinitario and Lower Amazon Forastero that have occurred at the early time of cocoa introduction to Africa. The lack of rDNA unit 4 in African Trinitario might therefore be the result of the dilution of American Trinitario genes into Lower Amazon Forastero genes. Moreover, almost all the Criollo are characterized by the unit 4 and only few Criollo bear only the rDNA unit 1 . As little is known about the origin of Criollo clones, these clones may have been considered as Criollo because of their morphological characteristics, but could in fact result from some ancient crossing with Forastero followed by fixation of morphological Criollo characters and Forastero rDNA units. It can be therefore concluded that the presence of a rDNA unit 4 is likely to be characteristic of Criollo types which makes rRNA gene analysis a powerful tool for discriminating Forastero and Criollo populations.

No relation with geographical conditions can be demonstrated as was done for rice (Sano \& Sano, 1990) and for Triticum dicoccoides (Flavell et al., 1986). Indeed, several clones from Costa Rica (MAT), which are supposed to originate from an introduction of the Brazilian Comun type (Soria, 1970), are grouped together with the Comun clone showing that no differentiation due to geographical changes has occurred.

The complexity of the evolution of rRNA genes leads to a very particular representation of the variability of the species. Considering all plant species, relations can be shown with ecological, morphological or isozyme characters either individually or jointly. It is, therefore, necessary to gather information from different kinds of markers (morphological characters, isozymic markers, RFLP, RAPD) to obtain a global view of species diversity.

The present results highlight the importance of RFLP markers to assess genetic variability in cocoa. Further studies using nuclear and cytoplasmic probes will be carried out to yield a more accurate description.

\section{Acknowledgements}

We thank Dr Reyes, Dr Fonseca, Dr Morera, Professor Spence, M. Sounigo and Ms Johnson for providing us with plant material. We are grateful to Dr Bartley and to Dr Lockwood for their comments on the manuscript and for information about the origins of clones and to Dr Delseny for his comments on the rDNA interpretation.

\section{References}

ALLEN, J. B. 1987. London cocoa trade Amazon project. Final report phase 2. Cocoa Growers'Bulletin, 39, special issue. APPELS, R. AND DVORAK, J. 1982. The wheat ribosomal DNA spacer region: its structure and variation in populations and among species. Theor. Appl. Genet., 63, 337-348.

CHEESMAN, E. E. 1944. Notes on the nomenclature, classification and possible relationships of cocoa populations. Tropical Agriculture, 2, 144-159.

DELCASSO-TREMOUSSAYGUE, D., GRELlet, F., PANABIERES, F., ANANIEV, E. D. AND DELSENY, M. 1988. Structural and transcriptional characterization of the external spacer of a ribosomal RNA nuclear gene from a higher plant. Eur. $J$. Biochem., 466, 1-10.

DELSENY, M., MCGRATH, J. M., THIS, P., CHEVRE, A. M. AND QUIROS, C. F. 1990. Ribosomal RNA genes in diploid and amphidiploid Brassica and related species: organization, polymorphism, and evolution. Genome, 33, 733-744.

FLAVELL, R. B., O'DELL, M., SHARP, P., NEVO, E., AND BEILES, A. 1986. Variation in the intergenic spacer of ribosomal DNA of wild wheat, Triticum dicoccoides, in Israel. Mol. Biol. Evol., 3, 547-558.

FigueIRA, A., JANICK, J. AND GoldSBrough, P. 1992. Genome size and DNA polymorphism in Theobroma cacao. J. Amer. Soc. Hort. Sci., 117, 673-677.

GERLACH, W. L. AND BEDBRoOK, J. R. 1979. Cloning and characterization of ribosomal RNA genes from wheat and barley. Nucleic Acids Res., 7, 1869-1885.

GLASZMAN, J. C. LU, Y. H. AND LANAUD, C. 1990. Variation of nuclear ribosomal DNA in sugarcane. J. Genet. Breed., 44, 191-198.

GLICENSTEIN, L. J. AND FRITZ, J. P. 1989. Meiosis in Theobroma cacao. Turrialba, 39(4), 497-500.

GRELLET, F., DELCASSO-TREMOUSAYGUE, D. AND DELSENY, M. 1989. Isolation and characterization of an unusual repeated sequence from the ribosomal intergenic spacer of the crucifer Sysimbrium irio. Plant Mol. Biol., 12, 695-706.

HARVEY, M. J. 1991. Molecular characterization of the interspecific origin of viviparous onion. J. Hered., 82(6), $501-503$.

HEMLEBEN, V., GANAL, M., GERSTNER, J., SCHIEBEL, K. AND TORRES, R. A. 1988. Organization and length heterogeneity of plant ribosomal RNA genes. In: Kahl, G. (ed.) Architecture of Eukaryotic Genes. Verlagsgesellschaft mbH. Weinheim, pp. 371-383. 
JORGENSEN, R. A., CUELLAR, R. E., THOMPSON, W. F. AND KAVANAGH, T. A. 1987. Structure and variation in ribosomal RNA genes of pea: characterization of a cloned rDNA repeat and chromosomal rDNA variants. Plant Mol. Biol., 8, 3-12.

KAVANAGH, T. E. AND TIMMIS, J. N. 1986. Heterogeneity in cucumber ribosomal DNA. Theor. Appl. Genet., 72, 337-345.

LANAUd, C. 1987. Nouvelles données sur la biologie du cacaoyer (Theobroma cacao L.): diversité des populations, système d'incompatibilité, haploïdes spontanés. Leurs conséquences pour l'amélioration génétique de cette espèce. Doctorat d'état, Université Paris XI.

LANAUD, C., LEAL, F. AND RODRIGUEZ, N. 1986. Rapport de prospection au Venezuela. IBPGR.

LEVESQUE, H., VEDEL, F., MATHIEU, C. AND DE COURCEL, A. G. L. 1990. Identification of a short rDNA spacer sequence highly specific of a tomato line containing $T m$-1 gene introgressed from Lycopersicon hirsutum. Theor. Appl. Genet., 80, 602-608.

PouND, F. P. 1938. Cacao and witches' broom disease
(Marasmius perniciosus) of South America. Reprinted in 1981, Archives of Cocoa Research, 1, 20-72.

ROGERS, S. O. AND BENDICH, A. J. 1987. Ribosomal RNA genes in plants: variability in copy number and in the intergenic spacer. Plant Mol. Biol., 9, 509-520.

SANO, Y. AND SANO, R. 1990. Variation of the intergenic spacer region of ribosomal DNA in cultivated and wild rice species. Genome, 33, 209-218.

SORIA, J. v. 1970. Principal varieties of cocoa cultivated in tropical America. Cocoa Growers' Bulletin, 19, 12-21.

TAIRA, T., KATO, A. AND TANIFUII, s. 1988. Difference between two major size classes of carrot rDNA repeating units is due to reiteration of sequences of about $480 \mathrm{bp}$ in the large spacer. Mol. Gen. Genet., 213, 170-174.

WILDE, J., WAUGH, R. AND POWELL. P. 1992. Genetic fingerprinting of Theobroma clones using randomly amplified polymorphic DNA markers. Theor. Appl. Genet., 83, 871-877.

ZIMMER, E. A., JUPE, E. R. AND WALBOT, v. 1988. Ribosomal gene structure variation and inheritance in maize and its ancestors. Genetics, 120, 1125-1136. 